\title{
PRAKTIK GADAI TANAH SAWAH DI DESA ALATENGAE MAROS SULAWESI SELATAN DALAM PERSPEKTIF SYARIAT
}

\section{THE PRACTICE OF PAWNING PADDY FIELDS IN THE VILLAGE OF ALATENGAE MAROS SOUTH SULAWESI IN SHARIA PERSPECTIVE}

\author{
A. Hawariah \\ Sekolah Tinggi Ilmu Islam dan Bahasa Arab (STIBA) Makassar, Indonesia \\ Email: andihawariah@stiba.ac.id \\ Kurnaemi Anita \\ Sekolah Tinggi Ilmu Islam dan Bahasa Arab (STIBA) Makassar, Indonesia \\ Email: pustakaarabic@gmail.com \\ Jujuri Perdamaian Dunia \\ Sekolah Tinggi Ilmu Islam dan Bahasa Arab (STIBA) Makassar, Indonesia \\ Email: jujuri@stiba.ac.id \\ Shofiyyah \\ Sekolah Tinggi Ilmu Islam dan Bahasa Arab (STIBA) Makassar, Indonesia \\ Email: shofiyyah@gmail.com
}

\begin{tabular}{ll}
\hline Keywords : & \multicolumn{1}{c}{ ABSTRACT } \\
pawn, paddy fields, sharia & This study aims to identify and reveal the practice system of pawning \\
paddy fields that often occurs in villages in Indonesia. This research is & a descriptive-qualitative research that describes various conditions, \\
situations or social phenomena that exist in rural communities. The \\
approach used is normative juridical to examine theories, concepts, \\
legal principles and laws and regulations related to this research by \\
emphasizing the facts that occur in the field. The research location \\
chosen was the village of Alatengae, Maros, South Sulawesi, as a \\
representative of a number of villages in Indonesia that often practice \\
pawning rice fields. After collecting and analyzing data regarding the \\
legal practice of pawning paddy fields that occurred, the reality of the \\
system of using pawned goods, in this case the pawned rice fields, is \\
contrary to Islamic law and can be categorized as usury, because it is \\
very detrimental to one party, namely the party who pawns. This is \\
because the function rights or the harvested rice fields are fully owned \\
by the party who received the pledge without any distribution of the \\
results. Even though the original law, utilization may be carried out by \\
the party receiving the pledge but only to return the costs used when \\
managing or working on the rice fields.
\end{tabular}


Diterima: 12 Oktober 2021; Direvisi: 25 Oktober 2021; Disetujui: 19 November 2021; Tersedia online: 3 Desember 2021

How to cite: A. Hawariah, Kurnaemi Anita, Jujuri Perdamaian Dunia, Shofiyyah, "Praktik Gadai Tanah Sawah di Desa Alatengae Maros Sulawesi Selatan dalam Perspektif Syariat", BUSTANUL FUQAHA: Jurnal Bidang Hukum Islam Vol. 2, No. 3 (2021): 472-487. doi: 10.36701/bustanul.v2i3.410.

\section{PENDAHULUAN}

Untuk mempertahankan kelangsungan hidup di masyarakat, manusia tidak akan terlepas dari berbagai masalah yang harus dihadapi, baik dalam hal ekonomi maupun masalah dalam aspek-aspek lain. Dalam masalah ekonomi sering kali manusia melakukan transaksi utang-piutang untuk memenuhi kekurangan dalam kelangsungan hidupnya, baik dengan menggunakan jaminan (biasa disebut hutang gadai) maupun tidak dengan jaminan. Utang-piutang adalah memberikan sesuatu kepada seseorang dengan perjanjian ia akan membayar nilai yang sama, ${ }^{1}$ sedangkan utang dengan jaminan (gadai atau rahn) menurut bahasa Arab adalah al-Śubūt atau al-Dawām yang berarti tetap. Ada pula yang menjelaskan bahwa rahn adalah menahan. ${ }^{2}$ Adapun secara istilah, rahn adalah menahan suatu benda secara hak yang memungkinkan untuk dieksekusi, maksudnya menjadikan suatu benda/barang yang memiliki nilai harta dalam pandangan syara' sebagai jaminan atas hutang, selama hutang tidak dapat dilunasi, dengan barang tersebut hutang dapat diganti baik keseluruhan atau sebagian. ${ }^{3}$

Pinjaman dengan menggadaikan marhun (barang gadai) sebagai jaminan marhun bih (hutang/pinjaman) dalam bentuk rahn itu dibolehkan, dengan ketentuan bahwa murtahin (penerima gadai) mempunyai hak menahan marhun sampai semua marhun bih dilunasi. Marhun dan manfaatnya tetap menjadi milik rahin yang pada prinsipnya tidak boleh dimanfaatkan oleh murtahin kecuali dengan seizin rahin, tanpa mengurangi nilainya serta sekedar sebagai pengganti biaya pemeliharaan dan perawatannya. Adapun pengertian gadai dalam hukum Islam yang dimaksud dengan rahn ialah:

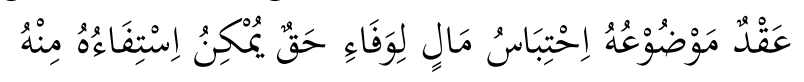

\footnotetext{
${ }^{1}$ Muhammad bin Mukrim Ibnu Manzūr, Lisānul 'Arab, Jilid 3 (Cet I; Beirut: Dār Șādir, 2010), h. 189.

${ }^{2}$ Muhammad bin Mukrim Ibnu Manzūr, Lisānul 'Arab, Jilid 4, h. 287.

${ }^{3}$ Wahbah al-Zuhailī, al-Fiqh al-Islāmī wa Adillatuhu. Jilid 4 (Cet. I. Bairūt: Dār al-Fikr, 2002), h. 128.
} 


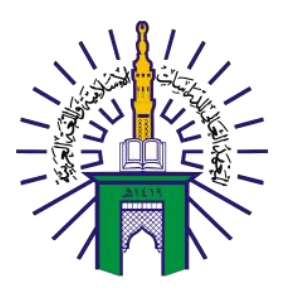

\section{BUSTANUL FUQAHA: \\ JURNAL BIDANG HUKUM ISLAM \\ Vol. 2 No. 3 (2021): Hal. 472-487 \\ EISSN: 2723-6021 \\ Website: https://journal.stiba.ac.id}

Artinya:

Akad yang objeknya menahan terhadap sesuatu hak yang mungkin diperoleh

bayaran yang sempurna darinya. ${ }^{4}$

Dalam Islam, gadai diatur mulai dari syarat atau akad dan rukunnya, tata caranya, hak dan kewajiban kedua belah pihak yang melakukan praktik gadai, hingga hukum pengambilan manfaat atas barang gadai dan tata cara berakhirnya proses gadai. Namun ada pula sebagian orang atau lembaga yang melakukan transaksi gadai tidak sesuai dengan ajaran Islam. Yakni terjadinya tindak kezaliman yang dilakukan pemilik piutang. Pada saat rahin melakukan transaksi sebenarnya ada unsur keterpaksaan karena mau tidak mau ia harus rida dengan ketentuan yang diberikan oleh murtahin berkaitan dengan pemanfaatan dikuasai sepenuhnya oleh murtahin yang kemudian dikelola dan hasilnyapun akan dinikmati oleh penerima gadai dan tidak adanya bagi hasil panen antara rahin dan murtahin sampai hak kepemilikan sawah tersebut kembali kepada rahin setelah melunasi pinjamannya. Tentunya hal ini akan sangat menguntungkan bagi pihak penerima gadai karena selain mendapatkan keuntungan dari hasil sawah, uang pokok yang dipinjam oleh pemberi gadai juga akan dikembalikan. Sedangkan dalam bermuamalah sendiri Islam mengajarkan untuk dilakukan atas dasar suka rela tanpa mengandung unsur paksaan dan yang harus diperhatikan adalah nilai-nilai keadilan jangan sampai mengambil kesempatan dalam kesempitan.

Para ulama fikih sepakat mengatakan bahwa barang yang dijadikan barang jaminan itu tidak boleh dibiarkan begitu saja tanpa menghasilkan sama sekali, karena tindakan itu termasuk tindakan menyia-nyiakan harta yang dilarang Rasulullah. Namun dalam praktek gadai tersebut murtahin (penerima gadai) mengambil manfaat yang bisa dikatakan berlebih dari tanah rahin. Dan dalam fikih muamalah dijelaskan bahwa hak murtahin kepada marhun hanya pada keadaan atau sifat kebendaannya yang mengandung nilai, tidak pada penggunaan dan pemungutan hasilnya. ${ }^{5}$

Dalam kontek hukum adat, gadai merupakan perjanjian yang berhubungan dengan tanah, artinya tanah bukan sebagai objek perjanjian melainkan sebagai jaminan atas perjanjian pinjam uang, dengan ketentuan dikembalikan atau tanah akan kembali setelah ditebus. Ketentuan yang demikian bisa mengarah ke riba yang dapat menyebabkan ketidakadilan. ${ }^{6}$ Namun kultur masyarakat yang plural menyebabkan hal ini telah menjadi kebiasaan yang sering dipraktikkan di Indonesia.

Masyarakat pedesaan khususnya petani di desa Alatengae Kecamatan Bantimurung Kabupaten Maros Sulawesi Selatan sering melakukan transaksi atau praktik gadai sawah. Gadai dalam istilah mereka disebut sanra. Praktik gadai yang dilakukan masyarakat terkadang menguntungkan dan juga merugikan terhadap kedua belah pihak, baik rahin ataupun murtahin. Salah satu contoh praktik gadai/sanra yang merugikan pihak yang menggadaikan sawahnya (rahin) adalah diambilnya hak kepemilikan sawah tersebut.

\footnotetext{
${ }^{4}$ Hasby Ash Shiddieq, Pengantar Fiqih Muamalah (Jakarta: Bulan Bintang, 1984), h. 86-87.

${ }^{5}$ Ahmad Azhar Basyir, Hukum Islam tentang Riba Utang Piutang Gadai (Cet. II; Bandung: al-Ma'arif, 1983), h.50.

${ }^{6}$ Abdul Ghofur Anshori, Hukum Perjanjian Islam Di Indonesia "Konsep, Regulasi, dan Implementasi" (Yogyakarta: Gadjah Mada University Press, 2010), h. 123-124.
} 
Hal itu disebabkan karena tidak adanya perjanjian hitam di atas putih atau bukti serah terima gadai tersebut pada awal akad gadai sawah di desa Alatengae, bahkan akadnya tanpa dihadiri oleh saksi. Sehingga beberapa tahun kemudian saat pihak rahin ingin mengambil kembali hak gadai sawah tersebut, pihak murtahin mengatakan bahwa sawah tersebut sudah menjadi miliknya, karena menurutnya transaksi yang dilakukan adalah bukan transaksi gadai, melainkan transaksi jual beli sawah. Kasus seperti ini sampai sekarang masih ditangani oleh pihak investigasi kepolisian di Kabupaten Maros. Praktik ini sudah menjadi kebiasaan turun temurun di desa tersebut sehingga sulit untuk memecahkan kebenaran akan hak milih sawah yang digadaikan. ${ }^{7}$

Artikel ini akan mengungkap dan menganalisa praktik gadai tanah sawah yang terjadi di tengah masyarakat pedesaan di Indonesia. Konsep rumusan masalah yang akan diangkat adalah: (1) Bagaimana realitas praktik gadai tanah sawah di desa Alatengae Maros Sulawesi Selatan?; dan (2) Bagaimana tinjauan hukum Islam terhadap praktik gadai tanah sawah tersebut?. Kemudian tujuan penelitian ini adalah untuk mengambarkan realita praktik gadai tanah sawah di desa Alatengae Maros Sulawesi Selatan dan menjelaskan hukum praktik gadai tanah sawah tersebut berdasarkan perspektif syariat Islam.

Penelitian ini merupakan penelitian kualitatif analitik dengan pendekatan yuridis normatif untuk mengetahui bagaimana tinjauan hukum Islam terhadap praktik gadai tanah sawah dengan yang dipraktikkan oleh umumnya masyarakat pedesaan di Indonesia. Lokasi penelitian yang dipilih adalah desa Alatengae Maros Sulawesi Selatan sebagai perwakilan masyarakat pedesaan yang biasa melakukan praktik gadai tanah sawah. Data diperoleh dari hasil pengamatan di lapangan dan wawancara kepada beberapa penduduk desa Alatengae yang pernah melakukan praktik gadai tersebut kemudian di sinkronisasikan dengan hukum Islam yang diperoleh dari beberapa literatur primer dan sekunder.

Terdapat beberapa kajian dan penelitan yang telah dilakukan terkait praktik gadai tanah sawah diantaranya penelitian yang dilakukan oleh Ahmad Irsyadul Ibad yang berjudul "Pemanfaatan Barang Gadai (Studi Komparatif Fiqh Empat Madzhab)". Penelitian ini mengungkapkan bahwa para ulama mazhab berselisih baik pemanfaatan dilakukan oleh rahin atau murtahin, serta membahas bagaimana perbandingan pemanfaatan barang gadai oleh rahin dengan melihat prespektif fiqh empat madzhab. ${ }^{8}$ Kemudian penelitian lapangan oleh Fitria Nursyarifah yang berjudul "Praktik Gadai Sawah Petani Desa Simpar Kecamatan Cipunagara Kabupaten Subang dalam Perspektif Fikih Muamalah". Penelitian ini menganalisa pemahaman para petani desa Simpar mengenai gadai dalam Islam dan mengetahui praktik gadai sawah yang para petani lakukan dalam perspektif fikih muamalah. ${ }^{9}$

Artikel ini kemudian mencoba menggali lebih spesifik permasalahan gadai tanah sawah berdasarkan fenomena yang terjadi pada suatu desa yang biasa

\footnotetext{
${ }^{7}$ H. Sembo (44 tahun), Tokoh Masyarakat, Wawancara, 11 Juni 2019.

${ }^{8}$ Ahmad Irsyadul Ibad, "Pemanfaatan Barang Gadai (Studi Komparatif Fiqh Empat Madzhab", Skripsi (Malang: Fakultas Syariah UIN Maulana Malik Ibrahim, 2017).

${ }^{9}$ Fitria Nursyarifah, "Praktik Gadai Sawah Petani Desa Simpar Kecamatan Cipunagara Kabupaten Subang dalam Perspektif Fikih Muamalah", Skripsi (Jakarta: Fakultas Syari'ah dan Hukum UIN Syarif Hidayatullah, 2015).
} 


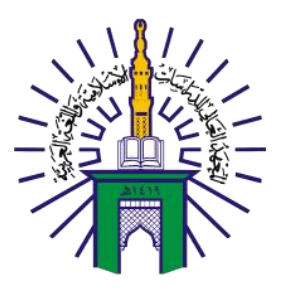

\section{BUSTANUL FUQAHA: \\ JURNAL BIDANG HUKUM ISLAM \\ Vol. 2 No. 3 (2021): Hal. 472-487 \\ EISSN: 2723-6021 \\ Website: https://journal.stiba.ac.id}

memperaktikkannya, kemudian mengeluarkan hukumnya berdasarkan perspektif syariat Islam. Implikasi dari penelitian diharapkan dapat membawa pencerahan di tengah masyarakat muslim dan dijadikan bahan untuk memahami hak-hak pihak yang menggadaikan (rahin) dan hak-hak pihak yang menerima gadai (murtahin) terhadap barang gadaian (marhun).

\section{PEMBAHASAN}

\section{Akad, Syarat dan Rukun Gadai}

Rukun gadai ada lima diantaranya yaitu pemberi gadai, penerima gadai, barang yang digadaikan, utang dan pernyataan gadai. Rahin (Pemberi Gadai atau Orang yang Menggadaikan), yaitu orang yang telah dewasa, berakal, bisa dipercaya dan memiliki barang yang akan digadaikan. Hak pemberi gadai (rahin) diantaranya: (a) Pemberi gadai berhak mendapatkan kembali barang gadai setelah ia melunasi pinjaman, (b) Pemberi gadai berhak menuntut kerugian dari kerusakan dan hilangnya barang gadai, apabila hal itu disebabkan kelalaian penerima gadai, (c) Pemberi gadai berhak menerima sisa hasil penjualan barang gadai setelah dikurangi biaya pinjaman dan biaya-biaya lainnya. ${ }^{10}$

Kewajiban pemberi gadai diantaranya adalah wajib melunasi pinjaman yang telah diterimanya dalam tenggang waktu yang ditentukan, termasuk biaya-biaya yang ditentukan oleh penerima gadai. Serta wajib melakukan penjualan atas barang gadai miliknya, apabila dalam jangka waktu yang ditentukan pemberi gadai tidak dapat melunasi pinjamannya ${ }^{11}$

Murtahin (Orang yang Menerima Gadai) bisa berupa individu, bank atau lembaga yang dipercaya oleh rahin untuk mendapatkan modal dengan jaminan barang. ${ }^{12}$ Sedangkan hak murtahin diantaranya adalah berhak menjual marhun apabila rahin tidak dapat memenuhi kewajiban pada saat jatuh tempo. Hasil penjualan barang gadai dapat digunakan untuk melunasi pinjaman dan sisanya dikembalikan kepada rahin. Murtahin juga berhak mendapatkan pengganti biaya yang telah dikeluarkan untuk menjaga keselamatan marhun. Dan selama pinjaman belum dilunasi, pemegang gadai berhak menahan barang gadai yang diserahkan oleh pemberi gadai. Adapun kewajiban murtahin yaitu bertanggungjawab atas hilangnya barang gadai apabila hal itu disebabkan kelalaiannya, tidak boleh menggunakan barang gadai untuk kepentingan pribadi, serta wajib memberitahu kepada rahin sebelum diadakan pelelangan barang gadai ${ }^{13}$

Marhun (Barang yang Digadaikan), yaitu barang yang dijadikan jaminan oleh rahin dalam mendapatkan utang. Sedang marhun bih (Utang), yaitu sejumlah dana yang diberikan murtahin kepada rahin atas dasar besarnya tafsiran marhun. Utang adalah kewajiban bagi pihak berutang untuk membayar kepada pihak yang memberi hutang. Adapun sigat (pernyataan gadai), yaitu kesepakatan antara rahin dan murtahin dalam melakukan transaksi gadai. ${ }^{14}$ Diantara yang menjadi syarat shigat: (a) Tidak boleh terikat dengan adanya syarat tertentu dan juga dengan suatu waktu dan masa depan, dan (b) Rahn

\footnotetext{
${ }^{10}$ Wahbah al-Zuhailī, al-Fiqh al-Islāmī wa Adillatuhu. Jilid 4, h. 128.

${ }^{11}$ Ahmad Irsyadul Ibad, Pemanfaatan Barang Gadai (Studi Komparatif Fiqh Empat Madzhab, h. 23-24.

${ }^{12}$ Rahmat Syafi'i, Fiqih Muamalah (Bandung: CV Pustaka Setia, 2001), h. 164.

${ }^{13}$ Ali Zainuddin, Hukum Gadai Syariah (Jakarta: Sinar Grafika, 2008), h. 21.

${ }^{14}$ Wahbah al-Zuhailī, al-Fiqh al-Islāmī wa Adillatuhu. Jilid 4, h. 132.
} 
mempunyai sisi pelepasan barang dan pemberian utang seperti halnya akad jual-beli. Maka tidak boleh diikat dengan syarat tertentu atau dengan suatu waktu di masa depan. ${ }^{15}$

Mengenai syarat gadai, ulama fikih mengemukakan sesuai dengan rukun gadai itu sendiri, yaitu: (a) Baligh dan cakap hukum, karena anak kecil yang mumayyiz (dapat membedakan antara yang baik dan buruk) boleh melakukan akad rahn, dengan syarat mendapatkan persetujuan dari walinya. ${ }^{16}$ (b) Shigat, yakni dalam akad itu tidak boleh dikaitakan dengan syarat tertentu atau dengan masa yang akan datang.

Syarat Marhun Bih harus merupakan hak yang wajib dikembalikan kepada pemiliknya, berupa hutang yang memungkinkan untuk dipenuhi dan dibayar dari marhun (barang yang digadaikan), serta harus diketahui dengan jelas dan pasti. Adapun syarat marhun antara lain: boleh dijual dan nilainya seimbang, bernilai harta dan dapat dimanfaatkan, jelas dan pasti, milik sah rahin, Tidak terikat dengan hak orang lain, dan boleh diserahkan baik materinya maupun manfaatnya ${ }^{17}$

Menurut Imam Syafii, jika sudah ada penguasaan, maka gadai berlaku dan sah. Karenanya orang yang menerima gadai tidak boleh meminjamkan dan lain sebagainya terhadap barang yang digadaikan. Menurut ulama-ulama yang mensyaratkan penguasaan sebagai syarat sah akad, ialah adanya syarat kelangsungannya. ${ }^{18}$ Adapun ulama Syāfi'iyah berpendapat bahwa pegadaian bisa sah bila memenuhi tiga syarat, yaitu pertama harus berupa barang, karena uang tidak bisa digadaikan. Kedua, penetapan kepemilikan pegadaian atas barang yang digunakan tidak terhalang. Dan ketiga, barang yang digadaikan bisa dijual manakala sudah masa pelunasan utang gadai dan orang yang menggadaikan belum dapat melunasi pinjaman. ${ }^{19}$

Berdasarkan tiga syarat di atas, maka dapat diambil alternatif dalam mekanisme perjanjian gadai, yaitu dengan menggunakan tiga akad perjanjian, yaitu: (a) Akad alQardu al-Hasan dimana akad ini dilakukan pada kasus nasabah yang menggadaikan barangnya untuk keperluan konsumtif. Dengan demikian nasabah akan memberikan biaya upah atau fee kepada pegadaian yang telah menjaga atau merawat barang gadaian (marhun). (b) Akad al-Mud̄ārabah yang dilakukan untuk nasabah yang menggadaikan jaminannya untuk menambah modal usaha (pembiayaan investasi dan modal kerja). Dengan demikian, rahin akan memberikan bagi hasil (berdasarkan keuntungan) kepada murtahin sesuai dengan kesepakatan, sampai modal yang dipinjam dapat dilunasi. (c) Akad $B \bar{a} ' i$ al-Muqayyadah yang biasa dilakukan jika rahin yang menginginkan menggadaikan barangnya untuk keperluan produktif, artinya dalam menggadaikan, rahin tersebut menginginkan modal kerja berupa pembeli barang. Sedangkan barang jaminan yang dapat dijaminkan untuk akad ini adalah barang-barang yang dapat dimanfaatkan atau tidak dimanfaatkan oleh rahin atau murtahin. ${ }^{20}$

\footnotetext{
15 Andri Soemitra, Bank dan Lembaga Keuangan Syariah, h. 391.

${ }^{16}$ Hendi Suhendi, Fiqh Muamalah, (Cet I; Jakarta: PT Raja Grafindo Persada, 2014), h. 107.

${ }^{17}$ Nusron Haroen, Fiqih Muamalah (Jakarta: Gaya Media Pratama, 2000), h. 255.

${ }^{18}$ Muhammad bin Ahmad Ibnu Rusyd, Bidayatul Mujtahid wa Nihayatul Muqtashid, terj. Abdul Rasyad Shiddiq, (Jakarta: Akbar Media Eka Sarana, 2015), h. 460.

${ }^{19}$ Annisa Budi Utami, Pegadaian Syariah. http://nisas-notes.blogspot.com (03 April 2019).

${ }^{20}$ Wahbah al-Zuhailī, al-Fiqh al-Islāmī wa Adillatuhu. Jilid 4, h. 145.
} 


\section{Gambaran Umum Desa Alatengae dan Pemahaman Petani Terhadap Gadai Tanah Sawah}

Desa Alatengae merupakan salah satu desa yang berada di wilayah kecamatan Bantimurung, Kabupaten Maros, Provinsi Sulawesi Selatan. Sejak keberadaannya, desa Alatengae sudah pernah mengalami pemekaran menjadi dua wilayah desa, yaitu desa Alatengae yang terdiri atas enam dusun dan karena kebutuhan masyarakat, saat ini dimekarkan lagi menjadi delapan dusun. Warga Desa Alatengae sebagian besar hidup bekerja di sektor pertanian, usaha ternak sapi, itik dan ayam. Semua diusahakan secara tradisional, di daerah tofografi yang datar. Hanya sedikit diantaranya yang bekerja di kantor pemerintah. Latar belakang pendidikan masyarakatnya juga masih sangat rendah. Hanya sekitar 3 persen diantaranya yang bergelar sarjana, sebagian besar hanya mengenyam pendidikan sampai sekolah menengah pertama dan sekolah menengah atas.

Pemahaman para petani mengenai aturan gadai dalam Islam masih sangat minim. Hal itu dapat diketahui dari hasil wawancara saat penulis meneliti. Mereka hanya memahami bahwa gadai atau sanra adalah transaksi meminjam uang dengan jaminan dimana ketika pihak rahin membutuhkan uang dan pihak murtahin membutuhkan jaminan. Gadai yang sesuai dengan ajaran Islam menurut mereka adalah gadai yang barang jaminannya jelas/ada tanpa memahami bahwa pemanfaatan barang gadai yang berlebih tidak seharusnya dilakukan oleh pihak murtahin. Jadi transaksi gadai sudah dianggap sebagai suatu transaksi yang bertujuan mencari keuntungan, bukan lagi tolongmenolong seperti tujuan gadai dalam Islam. Padahal proses gadai itu sendiri lebih sering dilakukan antar keluarga, namun sebagian mereka tidak mempermasalahkan keuntungan yang lebih banyak diperoleh oleh pihak yang memberikan pinjaman. Pemahaman yang minim tersebut salah satunya disebabkan kurangnya dakwah para tokoh agama mengenai tata cara bermuamalah yang sesuai dengan ajaran Islam, khususnya mengenai gadai. ${ }^{21}$

Uang jaminan yang didapatkan dari hasil menggadaikan sawah digunakan untuk berbagai macam keperluan, salah satunya untuk membiayai sekolah anaknya di sekolah kepolisian dan pemberi gadai pun mengambil keputusan untuk menggadaikan tanahnya tersebut kepada saudaranya yang bersedia untuk memberikan pinjaman hutang kepadanya. ${ }^{22}$ Dan faktor utama yang melatarbelakangi terjadinya praktik gadai di desa Alatengae adalah karena masyarakat lebih memilih transaksi gadai dengan sesama saudara atau kerabat dari pada meminjam di lembaga keuangan disebabkan prosedur yang ada pada lembaga keuangan rumit dan butuh proses yang lama sedangakan kebutuhan yang mereka inginkan harus segera dipenuhi karena sifatnya mendesak. Sehingga langkah yang paling tepat yang dapat diambil dalam rangka menyelesaikan permasalahan menurut mereka adalah melaksanakn transaksi praktik gadai dengan sesama saudara, kerabat atau tetangga. ${ }^{23}$

\section{Sistem Pelaksanaan Praktik Gadai Tanah Sawah di Desa Alatengae}

Menurut para responden bahwa prosedur dalam melaksanakan transaksi gadai sawah di desa Alatengae antara penggadai (rahin) dengan pihak penerima gadai

\footnotetext{
${ }^{21}$ H. Sembo ( 44 tahun), Tokoh Masyarakat, Wawancara, 11 Juni 2019.

${ }^{22}$ Abdul Hafid (51 tahun), Pihak yang Menggadaikan Sawah, Wawancara, 11 Juni 2019.

${ }^{23}$ H. Sembo (44 tahun), Tokoh Masyarakat, Wawancara, 11 Juni 2019.
} 
(murtahin) pada prinsipnya sama. Pihak rahin mencari lalu mendatangi sanak keluarga atau tetangga yang bersedia meminjamkan uangnya dengan jaminan sawah milih rahin. Namun akad gadai bisa saja dilakukan di salah satu rumah rahin atau murtahin. Prinsip akad yang kedua belah pihak lakukan hanya bermodalkan saling percaya satu sama lain sehingga tidak ada saksi dalam pelaksanaan akad gadai tanah sawah tersebut. Bahkan dahulu, selain tidak adanya saksi dalam akad, bukti transaksi gadai pun tidak tertuliskan dikertas kwitansi atau perjanjian di atas kertas tidak dilakukan, sehingga terkadang menyebabkan masalah beberapa tahun kemudian saat pihak rahin ingin melunasi hutangnya dan ingin mengambil alih kembali hak milik sawahnya. Namun sekarang setiap bukti transaksi gadai yang dilakukan oleh kedua belah pihak harus tertuliskan dikertas kwitansi pembayaran dan kwitansi tersebut terkadang hanya dipegang oleh pihak murtahin. $^{24}$

Bentuk pinjaman yang terjadi di desa Alatengae berupa rupiah atau ringgit dimana nilai ringgit dua kali lebih besar dari nilai rupiah. Rupiah dan ringgit disini bukan jenis mata uang, melainkan jenis emas yang berbentuk koin dimana nilai emas tersebut setiap tahunnya akan mengalami kenaikan harga. Ini berimbas juga terhadap naiknya nominal yang harus dikembalikan pihak rahin sehingga pihak murtahin akan mendapatkan keuntungan yang lumayan besar saat pihak rahin hendak melunasi pinjamannya, apalagi jika masa gadai terjadi selama bertahun-tahun.

Penentuan jumlah nominal pinjaman kepada pihak murtahin pada dasarnya tidak disesuaikan dengan jenis atau luas sawah yang digadaikan. Selama tanah sawah tersebut bisa dikelola, maka pihak rahin langsung menyebutkan jumlah nominal yang akan dipinjamnya dan setelah pihak murtahin memberikan pinjamannya maka saat itu pula hak fungsi sawah tersebut pindah kepada pihak murtahin seutuhnya. Menggarap sawah tersebut adalah hak murtahin dan hasil sawah tersebut adalah milik murtahin, kecuali jika yang menggarap sawah tersebut adalah pemilik sawah itu sendiri, barulah ada pembagian hasil panen untuk keduanya, namun jika pihak murtahin sendiri yang menggarapnya, maka selama masa gadai masih berjalan, hasil panen sawah tersebut seutuhnya dimiliki oleh pihak murtahin meskipun transaksi gadai tersebut telah berjalan selama bertahun-tahun.

Adapun mengenai jangka waktu pelunasan hutang, tidak ditentukan baik oleh pihak murtahin maupun pihak rahin. Kapan pihak rahin telah sanggup melunasi hutang kepada pih ak murtahin, saat itulah hak fungsi sawah kembali kepada pihak rahin meskipun masa gadai telah berjalan selama bertahun-tahun. Misalnya praktik gadai yang dilakukan oleh bapak Abdul Hafid (51 tahun) kepada bapak Borahiman (65 tahun). Masa praktik gadai tersebut telah berjalan selama 5 tahun. Pada saat itu harga 1 rupiah senilai adalah sebesar Rp 8.000.000,00.

Pada awalnya, bapak Abdul Hafid meminjam 4 rupiah untuk keperluan sekolah anaknya, kemudian satu tahun kemudian menambah pinjaman lagi sebesar 1 rupiah untuk tambahan biaya umrahnya. Sehingga total uang pinjaman yang diberikan kepada bapak Abdul Hafid adalah sebesar Rp 40.000.000,00. ${ }^{25} 1$ tahun 3 kali panen. 1 kali panen bisa menghasilkan Rp 2.000.000,00. Jika dihitung kasar, Rp 6.000.000,00/tahun $\times 5$

\footnotetext{
${ }^{24}$ Borahiman (65 tahun), Pihak yang Menerima Gadai Sawah, Wawancara, 11 Juni 2019.

${ }^{25}$ Abdul Hafid (51 tahun), Pihak yang Menggadaikan Sawah, Wawancara, 11 Juni 2019.
} 
tahun selama masa gadai tersebut, pihak murtahin bisa menghasilkan $\mathrm{Rp} \mathrm{Rp}$ 30.000.000,00. Hasil tersebut belum dikurangi dengan biaya perawatan dan biaya penggarapan. Biaya perawatan atau biaya penggarapan selama 1 kali panen bisa mencapai Rp 500.000,00 $\times 3$ kali panen/tahun $=R p 1.500 .000,00 \times 5$ tahun $=R p$ 7.500.000,00. Jadi hasil bersih yang bisa didapatkan bapak Borahiman dari sawah yang digadaikan kepadanya selama 5 tahun adalah Rp 22.500.000,00. Dari uraian tersebut dapat disimpulkan bahwa pihak penggadai (rahin) tidak diberi sedikitpun dari hasil keuntungan pengolahan sawahnya oleh pihak penerima gadai (murtahin). Hal ini terjadi kerena praktik pemanfaatan tanah sawah sudah menjadi kebiasaan sebagian masyarakat di desa Alatengae yang dilakukan secara turun temurun.

Menurut penduduk desa meminta bantuan finansial dengan jaminan hanya bermodalkan kepercayaan saja tidaklah mudah apalagi dalam jumlah yang banyak. Sehingga mau tidak mau pihak penggadai (rahin) harus merelakan sawahnya dimanfaatkan oleh pihak penerima gadai (murtahin) demi mendapatkan sejumlah pinjaman modal. Namun ada beberapa masyrakat yang tidak terlalu peduli dengan hasil panen yang sepenuhnya dimiliki pihak murtahin. Salah satu alasannya karena sawah yang digadaikan adalah sawah orangtuanya yang sudah meninggal. Uang yang diperoleh dari pihak murtahin kemudian digunakan untuk kebutuhan hidup keluarganya seharihari. $^{26}$

Pemanfaatan tanah gadai juga bisa terjadi bertahun-tahun lamanya, hingga sekarang pemilik sawah tersebut belum mampu melunasi hutangnya kepada pihak murtahin, bahkan hingga penerima gadai tersebut sudah tidak menerima gadai tanah sawah lagi. ${ }^{27}$ Penjualan atau pelelangan tanah sawah yang digadaikan hampir tidak pernah terjadi dikalangan petani desa Alatengae karena pihak penerima gadai (murtahin) sudah merasa sangat diuntungkan dengan hasil sawah yang mereka garap. Hal itu menyebabkan mereka tidak menuntut pihak rahin untuk membayar hutangnya dengan segera, bahkan pihak rahin terkadang menambah jumlah hutang asalkan pihak murtahin masih sanggup untuk memberi pinjaman sebelum pihak rahin melunasi pinjaman yang pertama.

Praktik gadai yang terjadi selama bertahun-tahun tidak jarang menyebabkan pihak penerima gadai (murtahin) tiba-tiba membutuhkan uang karena keperluan yang mendesak. Namun disisi lain, pihak rahin belum bisa melunasi pinjamannya saat pihak murtahin membutuhkan uang. Langkah menyambungkan kepada pihak ketiga pun dilakukan oleh kedua belah pihak. Pihak rahin maupun murtahin sama-sama mendatangi pihak ketiga untuk menyerahkan hak fungsi gadai tanah sawah kepadanya. Dan ketika pihak murtahin menerima sejumlah uang dari pihak ketiga, hak fungsi tanah sawah atau hak hasil tanah sawah jatuh kepada pihak ketiga. Namun pada saat pihak rahin ingin melunasi hutangnya dan mengambil alih hak sawahnya, pihak rahin harus melalui pihak murtahin yang sebelumnya, tidak langsung melalui pihak yang ketiga tadi. Keadaan tersebut hanya terjadi jika pihak murtahin benar-benar dalam kondisi yang mendesak dan membutuhkan uang tunai. Dan penyerahan kepada pihak ketiga harus atas persutujuan semua pihak.

\footnotetext{
${ }^{26}$ Ibu Mondeng (55 tahun), Pihak yang Menggadaikan Sawah, Wawancara, 07 Juni 2019.

${ }^{27}$ Ibu Hj. Hamdana (64 tahun), Pihak yang Menerima Gadai Sawah, Wawancara, 07 Juni 2019.
} 
Untuk lebih jelasnya, realitas praktik gadai tanah sewa di desa Alatengae kecamatan Bantimurung dapat disimpulkan sebagai berikut: (a) Penerima gadai memanfaatkan barang gadaian dalam hal ini tanah sawah untuk kepentingan pribadi dengan menggarap sawah tersebut dan seluruh hasilnya dimiliki oleh pihak penerima gadai (murtahin) selama pihak rahin belum mengembalikan pinjamannya, (b) Tidak ada sistem pelelangan atau penjualan tanah sawah yang diagadaikan oleh pihak murtahin apabila pihak rahin belum mampu melunasi pinjamannya dan tidak berhak mendapat penggantian biaya perawatan yang telah dikeluarkannya, (c) Pihak rahin tidak berhak menuntut ganti rugi atas kerusakan atau kehilangan barang gadai dalam hal ini sawah apabila hal itu disebabkan kelalaian pihak murtahin.

\section{Praktik Gadai Tanah Sawah Di Desa Alatengae Dalam Perspektif Syariat Islam}

Pada dasarnya, marhun yaitu tanah sawah tidak boleh diambil manfaatnya oleh murtahin, kecuali apabila mendapatkan izin masing-masing pihak yang bersangkutan. Hak pihak murtahin terhadap marhun hanya sebatas menahan dan tidak berhak menggunakan atau mengambil hasilnya. Begitupun selama marhun ada di tangan pihak murtahin sebagai jaminan hutang (marhun bih), pihak rahin tidak berhak menggunakan marhun. Selanjutnya untuk mengetahui tinjauan hukum Islam tentang pemanfaatan tanah sawah gadai yang terjadi di desa Alatengae, berikut penjabaran pandangan para ulama mazhab tentang pemanfaatan barang gadai.

a. Pemanfaatan Barang Gadai (marhun) oleh Pihak Pemberi Gadai (rahin).

Menurut sebagian ulama Hanafiyyah, pemanfaatan barang gadai atau marhun diperbolehkan secara mutlak. Sebagian lagi berpendapat tidak boleh secara mutlak, baik mengendarai, memakai barang marhun, menempati rumah atau mengelolah tanah/sawah yang menjadi barang gadaian. Mereka melarang pemanfaatan seperti itu karena hak menahan marhun berada ditangan murtahin sehingga ia memiliki hak yang tetap sampai akad itu berakhir. Jadi ketika rahin memanfaatkan marhun tanpa seizin murtahin berarti ia telah melakukan perbuatan yang melawan hukum. Apabila hak yang dimaksud dilakukan oleh rahin yang kemudian terjadi kerusakan pada marhun, maka rahin yang harus bertanggungjawab atas rusaknya marhun tersebut, sementara kewajiban membayar hutang harus tetap berada pada rahin walaupun barang itu rusak atau hilang. ${ }^{28}$

Ulama Mālikiyyah mempunyai pandangan yang lebih tegas dibanding mażhab yang lain. Mereka menetapkan bahwa tidak boleh bagi rahin untuk memanfaatkan marhun. Mereka juga menetapkan bahwa izin murtahin kepada rahin untuk memanfaatkan marhun menyebabkan akad rahn (gadai) menjadi batal, karena pemberian izin murtahin kepada rahin untuk memanfaatkan marhun disini dianggap sebagai pelepasan hak murtahin terhadap marhun. Namun dikarenakan pemanfaatan marhun adalah milik rahin, maka ia boleh menjadikan murtahin sebagai wakilnya dalam memanfaatkan marhun agar pemanfaatan marhun tidak sia-sia. ${ }^{29}$

${ }^{28}$ Abu Bakr bin Mas'ūd al-Kāsān̄̄ al-Hanafī, Badāi'u al-Ṣanā'I fì Tartīb al-Syarā'i, Jilid 6 (Cet. II; Beirut: Dār al-Kutub al-'Ilmiyyah, 2010), h. 324.

${ }^{29}$ Muhammad bin Ahmad al-Garnātī, al-Qawānīn al-Fiqhiyyah fì Talkhīṣ Mazhab al-Mālikiyyah (Cet. I; Lebanon: Dar Ibni Hazm, 1434 H/2015 M), h. 280. 
Ulama Syäfi 'îyyah mempunyai pandangan yang berbeda dengan mayoritas ulama lainnya. Menurut mereka, pihak rahin boleh memanfaatkan marhun sepanjang tidak mengurangi atau merusak nilai materil dari barang seperti mengendarai kendaraan, menempati rumah, memakai murtahin dan lain sebagainya dari harta barang gadaian. Kebolehan ini berdasarkan dalil hukum bahwa manfaat dari hasil barang gadai tersebut milik rahin dan tidak bisa dikaitkan dengan utang yang ditanggungnya. Mereka menguatkan pendapatnya berdasarkan hadīs Nabi Muhammad saw. yang diriwayatkan oleh Imam al-Bukhari:

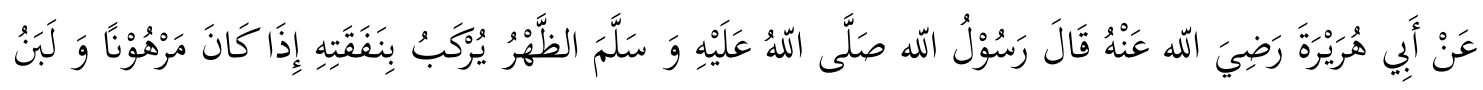

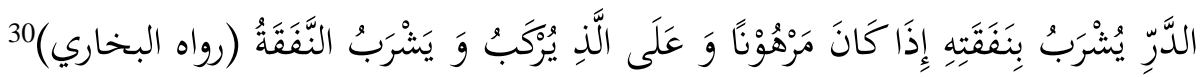

Artinya:

Dari Abu Hurairah ra., Rasulullah saw. bersabda, hewan boleh dinaiki berdasarkan nafkah dan pemeliharaannya ketika digadaikan dan susu hewan boleh diminum berdasarkan nafkah dan pemeliharaannya ketika hewan tersebut digadaikan. Pihak yang menaiki dan meminum susu hewan yang digadaikan adalah yang berkewajiban memberikan dan pemeliharaan terhadap hewan yang digadaikan tersebut

Jenis pemanfaatan yang dilarang menurut mereka adalah pemanfaatan yang mengurangi nilai marhun tersebut, seperti membangun gedung atau mengelola tanah yang masih dalam status gadai. namun pemanfaatan jenis ini menurut meraka diperbolehkan apabila rahin mengizinkan. Bagi ulama Syāfi'īyyah, bila barang yang digadaikan itu sesuatu yang sangat berarti bagi kehidupan rahin seperti rumah atau kendaraan yang setiap hari dipakai, maka rahin boleh memanfaatkan barang-barang tersebut sampai kebutuhannya terpenuhi. ${ }^{31}$

Ulama Hanābilah mempunyai pendapat yang sama dengan ulama Hanafiyyah, yaitu menelantarkan barang gadai bertentangan dengan syara'. Karena itu rahin dan murtahi harus melakukan kesepakatan-kesepakatan dalam pemanfaatan barang gadai (marhun) seperti mengendarai, menempati rumah, mengambil air susu binatang ternak dan lain sebagainya yang masih dalam perjanjian tanpa seizin murtahin. Ketika rahin dan murtahin tidak mencapai kesepakatan dalam penentuan batas-batas kebolehan pemanfaatan, maka barang gadai harus dibiarkan karena merupakan barang tertahan dari pemanfaatan sampai rahin melunasi utangnya. ${ }^{32}$

b. Pemanfaatan Barang Gadai (marhun) oleh Pihak Penerima Gadai (murtahin)

Pada sistem praktik gadai, barang gadai berada ditangan murtahin sehingga murtahin hanya berhak menahan, tetapi bukan mengambil manfaat dari barang tersebut atau memilikinya. Pada permasalahan ini, para ulama berbeda pendapat dalam hal

\footnotetext{
${ }^{30}$ Abū 'Abdillāh Muhammad bin Ismā’̄̄l bin Ibrāhīm al-Bukhari. Șaḥịh al-Bukhāri (Cet. I; Damaskus: Dar Ibnu Kasir, 1423 H/2002 M), h. 987.

${ }^{31}$ Ahmad bin Hamzah al-Ramlī, Nihāyatul Muhtāj Ilā Syarhil Minhāj, Jilid 6 (Cet. III; Beirut; Dar alKutub al-'Ilmiyyah, 1424 H/2011 M), h. 256.

32 'Abdullah bin Muhammad Ibnu Qudāmah al-Ḥanbalī, al-Mugn̄̄, Jilid 8 (Cet. III; Kairo: Dar 'Alam al-Kutub, 1417 H/1997 M), h. 224.
} 


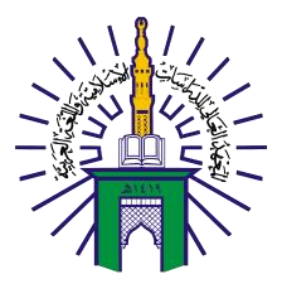

\section{BUSTANUL FUQAHA: \\ JURNAL BIDANG HUKUM ISLAM \\ Vol. 2 No. 3 (2021): Hal. 472-487 \\ EISSN: 2723-6021 \\ Website: https://journal.stiba.ac.id}

pemanfaatan barang gadai oleh murtahin. Perbedaan pendapat tersebut dikemukakan sebagai berikut:

Ulama Hanafiyyah berpendapat bahwa murtahin tidak boleh memanfaatkan marhun, baik itu dalam bentuk penggunaan, menaiki, menempati, mengenakan kecuali dengan izin rahin, karena murtahin hanya memiliki hak menahan saja bukan memanfaatkan. Apabila murtahin memanfaatkan marhun, lalu marhun itu rusak ketika digunakan, maka ia mengganti nilai marhun secara keseluruhan, karena berarti ia telah menggunakannya. Dan apabila rahin memberi izin kepada murtahin untuk memanfaatka marhun, maka menurut sebagian ulama Ḥanafiyyah, murtahin boleh memanfaatkannya secara mutlak. Namun ada sebagian lagi yang melarangnya secara mutlak.

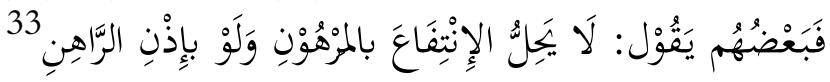

Artinya:

Sebagian dari mereka (ulama Hanafiyyah) mengatakan bahwa murtahin tidak boleh memanfaatkan barang gadai meskipun atas izin dari rahin

Sebagian mereka mengatakan tidak ada jalan yang mengharuskan murtahin menggunakan barang gadai walaupun dengan izin rahin, karena itu adalah riba atau mengandung syubhat, sedangkan izin atau persutujuan tidak bisa menghalalkan riba. Tetapi mayoritas mereka membolehkan murtahin menggunakan marhun bila ada izin dari rahin, dengan syarat hal tersebut tidak disyaratkan pada waktu akad. Bila hal tersebut disyaratkan pada waktu akad, maka hal pemanfaatan gadai tersebut termasuk riba.

Adapun pendapat ulama Mālikiyyah tentang hasil dari marhun dan segala sesuatu yang dihasilkan dari padanya, adalah termasuk hak rahin. Hasil gadaian itu adalah bagi rahin, selama murtahin tidak mensyaratkan. Dan apabila murtahin mensyaratkan bahwa hasil marhun itu untuknya, maka hal itu dapat saja terjadi dengan beberapa syarat, sebagai berikut: (a) Utang disebabkan karena jual beli, bukan karena menghutangkan. Hal itu dapat terjadi, seperti orang menjual barang dengan harga tangguh (tidak dibayar kontan), kemudian orang tersebut memintai gadai dengan suatu barang sesuai dengan nilai utangnya, maka hal itu diperbolehkan. (b) Pihak murtahin mensyaratkan bahwa manfaat dari marhun adalah untuknya. (c) Jangka waktu mengambil manfaat yang telah ditentukan, apabila tidak ditentukan dan tidak diketahui batas waktunya, maka menjadi batal dan tidak sah. Pendapat ulama Mãalikiyyah tersebut adalah bahwa yang berhak mengambil manfaat dari marhun adalah pihak rahin, namun murtahin pun dapat mengambil manfaat dari marhun dengan syarat yang telah disebutkan di atas. ${ }^{34}$

Ulama Syäfi'ìyah secara garis besar berpendapat seperti pendapat ulama Māalikiyyah, yaitu murtahin tidak boleh memanfaatkan barang yang digadaikan (marhun) bila hal itu diisyaratkan dalam akad. Namun apabila rahin mengizinkan hal tersebut sebelum akad, maka pemanfaatan marhun sesudah akad oleh murtahin adalah boleh. ${ }^{35}$ Hal ini berarti pemanfaatan marhun oleh murtahin tidak boleh disyaratkan

33 'Abdu rraḥman Al-Jazīrī, al-Fiqh 'alā al-Mażāhib al-Arba'ah (Bairūt: Dār al-Kutub al-'Ilmiyyah, 2003), h. 300.

${ }^{34}$ Muhammad bin Ahmad al-Garnātī, al-Qawānīn al-Fiqhiyyah fì Talkhīṣ Mazhab al-Mālikiyyah, h. 282

${ }^{35}$ Ahmad bin Hamzah al-Ramlī, Nihāyatul Muhtāj Ilā Syarhil Minhāj, h. 264. 


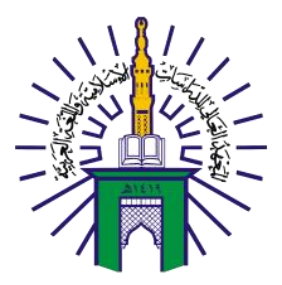

\section{BUSTANUL FUQAHA: \\ JURNAL BIDANG HUKUM ISLAM \\ Vol. 2 No. 3 (2021): Hal. 472-487 \\ EISSN: 2723-6021 \\ Website: https://journal.stiba.ac.id}

diawal akad, namun jika rahin mengizinkan memanfaatkan marhun maka hal itu diperbolehkan. Sebab hak kepemilikan atas marhun adalah ditangan rahin, oleh karena itu ia boleh secara bebas mengizinkan siapa saja yang dikehendaki untuk memanfaatkan marhun.

Ulama Hanābilah berpendapat kalau marhun berupa barang bukan hewan yang tidak diperlukan biaya untuk pemeliharaan seperti rumah, perhiasan dan lain-lain, maka murtahin dilarang memanfaatkan barang-barang tersebut tanpa seizin rahin. Namun bila ada izin dari rahin mengenai pemanfaatan yang dilakukan oleh murtahin atas marhun maka hal itu diperbolehkan menurut ulama Hanābilah. ${ }^{36}$ Apabila marhun berupa hewan, maka murtahin boleh memanfaatkannya apabila hewan tersebut adalah hewan yang bisa dikendarai atau hewan perah, namun dengan syarat menaikinya dan memerah susunya disesuaikan dengan kadar nafkah dan biaya kebutuhan marhun yang dikeluarkan oleh murtahin, dengan tetap memperhatikan sikap dalam memberi nafkah dan biaya kehidupan marhun, meskipun rahin tidak mengizinkan hal tersebut. ${ }^{37}$ Pendapat mereka dalam hal yang dimaksud, berdasarkan hadis Nabi Muhammad saw.

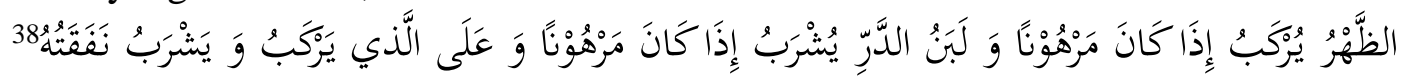

Artinya:

Punggung hewan tunggangan yang digadaikan boleh dinaiki, susu hewan ternak yang digadaikan boleh diminum dan yang menanggung nafkah hewan tersebut adalah yang menaiki dan meminumnya.

\section{Analisis Praktik Gadai Tanah Sawah Dari Sisi Akad, Rukun Dan Syaratnya}

Jika dilihat dari pihak yang melaksanakan akad, praktik gadai yang ada dan sedang berlangsung di desa Alatengae telah dipandang sah dan benar menurut hukum Islam meskipun tidak adanya saksi, namun adanya shigat (pernyataan gadai) berupa kwitansi dan adanya barang jaminan telah memenuhi sahnya akad. Rahin selaku pihak yang menggadaikan sawahnya dan murtahin selaku pihak yang menerima gadai telah memenuhi syarat yang telah diatur dalam aturan Islam, dimana keduabelah pihak adalah orang yang cakap dalam melakukan tindakan hukum, telah balig, tidak gila dan mampu untuk melakukan akad tanpa harus mewakilkan kepada orang lain.

Dilihat dari rukun gadai berupa hutang yang menjadi penyebab adanya transaksi gadai tersebut juga telah sah dan sesuai dengan hukum Islam, meskipun praktik gadai tanah sawah yang terjadi di desa Alatengae kecamatan Bantimurung menggunakan sistem rupiah atau ringgit hal ini dikarenakan hutang tersebut dapat dihitung jumlahnya, bukan hutang yang bersifat tidak pasti ataupun hutang yang tidak dapat diketahui jumlahnya. Hanya saja dengan sistem tersebut saat akan dilakukan pelunasan oleh pihak rahin telah mengandung unsur riba, disebabkan nilai rupiah atau ringgit terus naik seiring berjalannya waktu.

\footnotetext{
36 ‘Abdullah bin Muhammad Ibnu Qudāmah al-Ḥanbalī, al-Mugnī, h. 304.

37 ‘Abdullah bin Muhammad Ibnu Qudāmah al-Ḥanbalī, al-Mugnī, h. 304.

38 'Abdullah bin Muhammad Ibnu Qudāmah al-Ḥanbalī, al-Mugnī, h. 305.
} 


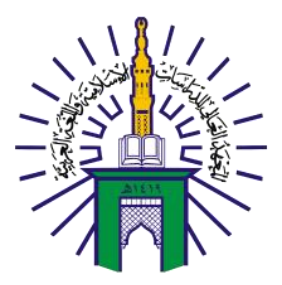

\section{BUSTANUL FUQAHA: \\ JURNAL BIDANG HUKUM ISLAM \\ Vol. 2 No. 3 (2021): Hal. 472-487 \\ EISSN: 2723-6021 \\ Website: https://journal.stiba.ac.id}

\section{Analisis Praktik Gadai Tanah Sawah Dari Sisi Pelaksanaannya Berupa Pemanfaatan Barang Gadai}

Pemanfaatan tanah sawah gadai yang terjadi di desa Alatengae jelas bertentangan dengan hukum Islam. Hal tersebut tentu sangat merugikan pihak rahin terlebih jika masa gadai berlangsung lama dan berlarut-larut, karena selain pihak rahin menanggung beban hutang, ia juga harus kehilangan manfaat dari sawah yang dijadikan jaminan hutang dalam waktu yang cukup lama dan seperti tidak lagi memiliki hak atas tanah sawah yang digadaikan. Apabila tanah sawah yang menjadi barang jaminan gadai tidak boleh dimanfaatkan oleh kedua belah pihak karena pihak rahin hanya memiliki barang tersebut, sementara pihak murtahin tidak memiliki hak untuk mengambil manfaat barang tersebut atau tidak mendapatkan hasil panennya, maka yang terjadi akan menyebabkan kerusakan pada tanah sawah yang digadaikan dan tidak mendatangkan manfaat.

Namun hal itu tidak pernah terjadi sepanjang praktik gadai tanah sawah terjadi di desa Alatengae. Kapan akad gadai telah disepakati, saat itu pula hak fungsi atau hasil panen sawah sepenuhnya menjadi milik murtahin. Kalaupun pihak murtahin tidak berkeinginan atau tidak sempat untuk merawatnya sendiri, pihak murtahin akan mencari orang untuk menggarap atau mengurus sawah tersebut selama masa gadai. Tidak jarang penggarapan tanah sawah gadai dilakukan oleh pihak rahin (pemilik sawah) atas kesepakatan keduabelah pihak, namun hal ini sangat jarang terjadi di tengah masyarakat yang terlibat dalam urusan gadai. Dan jika pihak rahin boleh melakukan penggarapan tanah sawah, barulah hasil panen sawah gadai tersebut bisa dibagi dua berdasarkan hasil kesepakatan. Praktik pemanfaatan tanah sawah yang digadaikan sudah merupakan bentuk pemerasan atau pengambilan harta orang dengan cara batil meskipun pihak rahin rida, namun ada unsur keterpaksaan di dalamnya. Dalam hal ini Allah swt. berfirman dalam Q.S An Nisā /4: 29

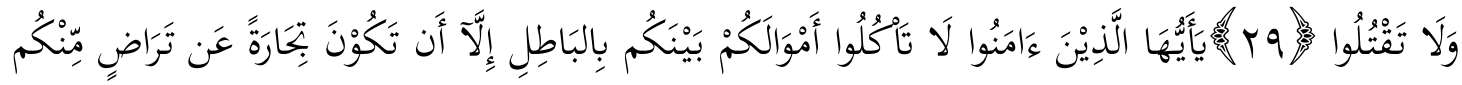

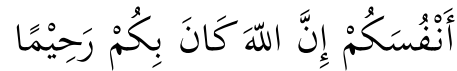

Terjemahnya:

Hai orang-orang yang beriman, janganlah kamu saling memakan harta sesamamu dengan jalan yang batil (tidak benar), kecuali dalam perdagangan yang berlaku atas dasar suka sama suka di antara kamu. Dan janganlah kamu membunuh dirimu . Sungguh, Allah Maha Penyayang kepadamu. ${ }^{39}$

\section{KESIMPULAN}

Realitas pelaksanaan praktik gadai tanah sawah di desa Alatengae kecamatan Bantimurung yaitu tidak adanya jangka waktu yang disepakati kapan pihak rahin harus melunasi pinjaman. Sehingga tidak jarang masa gadai berlangsung bertahun-tahun dan selama itu pula pihak murtahin mempunyai hak fungsi atau hak mengambil hasil panen sawah tersebut, bukan sekedar mengambil hasil untuk biaya perawatan yang dikeluarkannya selama mengelola marhun (tanah sawah). Alasan pihak rahin

\footnotetext{
${ }^{39}$ Kementrian Agama RI, al-Qur'ān Terjemahan (t. Cet; Bandung: Syāmil al-Qur'an, 2012), h. 83.
} 


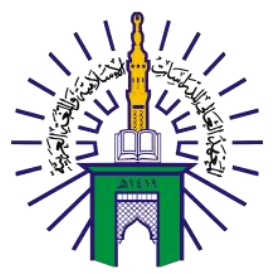

\section{BUSTANUL FUQAHA: \\ JURNAL BIDANG HUKUM ISLAM \\ Vol. 2 No. 3 (2021): Hal. 472-487 \\ EISSN: 2723-6021 \\ Website: https://journal.stiba.ac.id}

menggadaikan sawah mereka adalah dikarenakan kebutuhan yang mendesak dan membutuhkan uang tunai.

Sistem praktik gadai tanah sawah di desa Alatengae kecamatan Bantimurung memberikan pinjaman bukan berupa uang tunai, melainkan emas rupiah atau ringgit. Dan saat pelunasan pinjaman dilakukan, telah terjadi unsur riba dikarenakan nilai rupiah atau ringgit setiap tahunnya meningkat. Dan saat pengembalian pinjaman kepada pihak murtahin harus dalam bentuk rupiah atau ringgit pula, namun jika tidak memiliki rupiah atau ringgit, pihak murtahin harus mendatangi tempat jual beli emas untuk mengetahui nilai rupiah atau ringgit diwaktu tersebut, lalu menyerahkan uang dalam bentuk tunai sesuai dengan nilai rupiah atau ringgit tersebut kepada pihak murtahin. Dan akad pun berakhir ketika pihak rahin telah melunasi pinjamannya dan hak milik dan hak fungsi sawah kembali kepada pemiliknya (pihak rahin). Praktik gadai tanah sawah yang terjadi di desa Alatengae kecamatan Bantimurung jika ditinjau dari segi pelaksanaan akad sudah memenuhi rukun dan syarat gadai. Namun mengenai pemanfaatan atau pengambilan hasil sawah yang dikuasai penuh oleh pihak murtahin telah bertolakbelakang dengan hukum Islam mengenai tata cara pemanfaatan barang gadaian, bahkan bisa dikatakan tidak sah menurut al-qur'an, al-hadis dan ijma' ulama.

\section{DAFTAR PUSTAKA}

Afandi, Yazid. Fiqh Muamalat dan Implementasinya dalam Lembaga Keuangan Syari'ah. Yogyakarta: Logung Pustaka, 2009.

Ali, Muhammad Daud. Hukum Islam: Pengantar Ilmu Hukum dan Tata Hukum Islam di Indonesia. Cet. I. Jakarta: Rajawali Pers, 2001.

al-Garnātī, Muhammad bin Ahmad. al-Qawānīn al-Fiqhiyyah fì Talkhīṣ Mazhab alMālikiyyah. Cet. I; Lebanon: Dar Ibni Hazm, 1434 H/2015 M.

Al-Jazīrī, 'Abdu rraḥman. al-Fiqh 'alā al-mażāhib al-arba'ah. Bairūt: Dār al-Kutub al'Ilmiyyah, 2003.

al-Ramlī, Ahmad bin Hamzah. Nihāyatul Muhtāj Ilā Syarhil Minhāj. Jilid 6. Cet. III; Beirut; Dar al-Kutub al-'Ilmiyyah, 1424 H/2011 M.

al-Zuhailīi, Wahbah. al-Fiqh al-Islāmī wa Adillatuhu. Jilid 5. Cet. I. Bairūt: Dār al-Fikr, 2002.

Anggraini, Fita, dkk. "Sistem Tanam dan Umur Bibit Pada Tanaman Padi Sawah (Oryza sativa L.) Varietas Inpari 13.” Jurnal Produksi Tanaman 1, no. 2 (2013): h. 1-39.

Anshori, Abdul Ghofur. Hukum Perjanjian Islam Di Indonesia "Konsep, Regulasi, dan Implementasi”. Yogyakarta: Gadjah Mada University Press, 2010.

Arikunto, Suharsimi. Prosedur Penelitian Suatu Pendekatan Praktek. Jakarta: PT. Rineka Cipta, 1986.

Asy Syariah. Redaksi. Ketentuan tentang Pegadai, Penggadai, dan Barang Gadaian. http://asysyariah.com. (11 November 2018).

Azhary, Tahir. Beberapa Aspek Hukum Tata Negara, Hukum Pidana dan Hukum Islam. Cet II. Jakarta: Prenadamedia Group, 2015.

Basyir, Ahmad Azhar. Hukum Islam tentang Riba Utang Piutang Gadai. Cet. II; Bandung: al-Ma'arif, 1983.

Bikri, Cik Hasan. Model Penelitian Kitab Fikih. Cet. I. Bogor: Kencana, 2003.

Djuwaini, Dimyauddin. Pengantar Fiqh Muamalat. Yogyakarta: Pustaka Pelajar, 2008. 


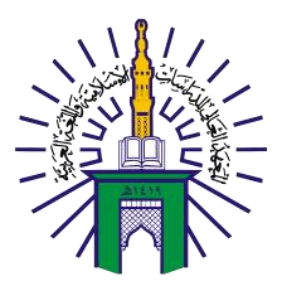

\section{BUSTANUL FUQAHA: \\ JURNAL BIDANG HUKUM ISLAM \\ Vol. 2 No. 3 (2021): Hal. $472-487$ \\ EISSN: 2723-6021 \\ Website: https://journal.stiba.ac.id}

Hardjowigeno, Sarwono dan M. Luthfi Rayes. Tanah Sawah dan Teknologi Pengelolaanny. Jawa Barat: Pusat Penelitian dan Pengembangan Tanah dan Agroklimat, 2004.

Haroen, Nusron. Fiqih Muamalah. Jakarta: Gaya Media Pratama, 2000.

Ibnu Qudāmah, Abdullah bin Muhammad al-Ḥanbalī. al-Mugnī. Jilid 8. Cet. III; Kairo: Dar 'Alam al-Kutub, 1417 H/1997 M.

Ibnu Rusyd Muhammad bin Ahmad. Bidāyatul al-Mujtahid wa Nihāyatul al-Muqtashid. Cet. I. Qahirah: Dārul al-Hadīs al-Qāhirah, 1425 H/2004 M.

Juliana. "Konsep Pemanfaatan Barang Gadai menurut Ibnu Qudamah dan Relevansinya terhadap Bisnis Pegadaian Syariah Kontemporer." Skripsi. Riau: Fak. Syari'ah dan Ilmu Hukum Universitas Islam Negeri Sultan Syarif Kasim Pekanbaru Riau, 2010.

Latumaeirissa, Julius. Bank dan Lembaga Keuangan Lain. Jakarta: Salemba Empat, 2013.

Mujburrahman. Pengertian Hukum Islam. http://studihukum.wordpress.com (26 Maret 2019).

Nursyarifah, Fitria. "Praktik Gadai Sawah Petani Desa Simpar Kecamatan Cipunagara Kabupaten Subang dalam Perspektif Fikih Muamalah.” Skripsi. Jakarta: Fakultas Syari'ah dan Hukum UIN Syarif Hidayatullah, 2015.

Rianse, Usman dan Abdi. Metodologi Penelitian Sosial Ekonomi Teori dan Aplikasi. Bandung: Alfabeta, 2012.

Soemitra, Andri. Bank dan Lembaga Keuangan Syariah. Cet. IV. Jakarta: Kencana, 2014.

Suhendi, Hendi. Fiqh Muamalah. Cet I; Jakarta: PT Raja Grafindo Persada, 2014.

Suhrawardi dan Chairuman. Hukum Perjanjian dalam Islam. Jakarta: Sinar Grafika, 1996.

Syaltūt, Maḥmūd. Al-Islām Aqīdah wa Syarī’ah. Cet. III. Kairo: Dār al-Qalam, 1996.

Utomo, Setiawan Budi. Perbankan Syariah. Cet. II. Jakarta: PT Raja Grafindo Persada, 2014.

Zainuddin, Ali. Hukum Gadai Syariah. Jakarta: Sinar Grafika, 2008. 